\title{
POVERTY AND ECONOMIC GROWTH: A REVIEW
}

\author{
Marinko ŠKARE, Romina PRŽIKLAS DRUŽETA \\ Faculty of Economics and Tourism "Dr Mijo Mirkovic", Juraj Dobrila University of Pula, Pula, Croatia
}

Received 15 April 2015; accepted 04 November 2015

\begin{abstract}
The objective of this paper is to review and attempt a synthesis of the relevant literature on growth versus poverty, and to analyze the causal link between the two phenomena. Research issues that drive our study are: Does economic growth tend to "raise all boats" as Kuznets (1955) pointed out? What is the role of the pattern of growth in the process of development? Which factor must we consider in designing appropriate pro-poor growth policies? This paper finds considerable variation in the poverty-reducing effectiveness of growth across time and authors. Also, our analysis speaks in favour of the fact that as growth occurs poverty reduces, no matter the level of inequality. Identically, similar growth pattern has different effects on poverty reduction. We conclude that growth is good for poverty alleviation but it is not enough. The extent to which growth reduces poverty depends upon how we measure poverty, and upon absorptive capacity of the poor, the pace and pattern of growth. In times when the rich are getting richer and the poor are getting poorer, "trickle-down" effect becomes a scenario that need to be reviewed.
\end{abstract}

Keywords: poverty, economic growth, trickle down effect, pro-poor and pro-growth policies.

JEL Classification: I30, I32, I38, I39, O47.

\section{Introduction}

The fight against poverty is the primary goal of modern development of economies of the $21^{\text {st }}$ century (Millennium Development Goal). However, the nature of poverty and economic growth has been at the centre of research of economic philosophers even in ancient Greece, Rome, India, Egypt and Babylon.

Analysis and knowledge on poverty and economic growth have changed dramatically over time, especially in the last decade. Attitude about the role of growth in poverty reduction is not the same as it was in 1950s or 1970s. Traditional theories of development have been studied separately from the phenomena of growth and poverty. Such an exogenous view of the early debates of the second half of the 20th century led to a tolerance of

Corresponding author Marinko Škare

E-mail:mskare@unipu.hr 
inequality in income and poverty duration and it was based on "trickle-down" approach (according the assumption that growth will automatically eliminate poverty), and the tradeoff between growth and income inequality. From the 1950s to early 70s, the focus was on the contribution of Kuznets' inter-binding U - curve (1955); Rostow's upswing phase (1960); Nurkse's system of useful or evil circles (1953), and some other theories that denied distribution of wealth. But in the '70s, as the golden years went by, it has been noticed that despite high growth rates, unemployment and poverty also grew along. The neoclassical doctrine that prevailed then did not find solutions that offered proper explanation for the negative market externalities.

Chenery et al. (1974) pointed out that although the average per capita income of the Third World has increased by fifty percent since 1960, it is clear that such rapid growth has been of little benefit to perhaps a third of their population.

Due to a very unequal distribution between countries, regions within countries and socio-economic groups, the growth policy and the idea of aggregate growth have been called into question.

By the end of the years of rapid growth of the 70s and a significant increase in poverty and inequality of the 80 s and 90 s, it became obvious that it is not possible to examine growth separately from poverty, and that economies do not have to converge unconditionally. New theoretical contributions of the 80s and the 90 s connect the two phenomena and emphasize a unified approach to economic growth and poverty, e.g. Datt and Ravallion (1992), Kakwani (1993), Person and Tabellini (1994), Deininger and Squire (1996), Easterley (2000), Dollar and Kraay (2002), Bourguignon (2003), Adams (2004), Ferreira (2010), Fosu (2010), Quah (2003) and many others. Furthermore, lately, new multidimensional measures and "tools" to measure poverty are being developed.

Despite advances in research, due to complexity of the subject-matter and the lack of methodological explorations (especially in the field of measuring poverty) consensus in this area has not yet been reached. However, the development of new endogenous theories led to a realization that persistence of poverty is not the result of available food shortage, but of the collapse of appropriate mechanisms, as growth is not limited to homoeconomicus as exists in industrialized countries (which is best confirmed by the experience of growth during the golden years) and that poverty reduction will not happen simply if the economy is growing.

According to Meier and Stiglitz (2001) today as billions of people still live in poverty it becomes clear that the "trickle-down" theory must be supplemented by policies of inclusion that lessen sharp disparities in incomes and assets, enhance human capital accumulation and employment opportunities, and help in providing safety nets for the more vulnerable elements of a society.

In this paper we begin from the assumption that economic growth and poverty are not separated phenomena, but the same phenomenon with two faces and that economic growth has a positive impact on poverty reduction but not by default. So, the trickle-down effect in the absence of pro-poor impact has no stronger scientific backing.

Transformation of economic growth in reducing poverty requires monitoring and re-examination of the methodology of measuring poverty (see more in Kakwani 2010; 
Škare, Pržiklas Družeta 2014) and a deeper analysis of the nature of poverty and pattern of economic growth. It is very important in what is invested in growth and whether it was effective. So, the elasticity of poverty and economic growth depends largely upon the quality and the very pattern of economic growth and the implementation of economic and social policy (pro-poor and pro-growth).

Moreover, an important fact is to shade new light on understanding how economic systems truly work. Without having the knowledge on the nature and quantitative dynamic relation between golden triangle law (employment, inflation, growth) prosperous and stable economic activity cannot be maintained (Škare 2014).

The core research question that guided this paper are: What is the impact of economic growth versus the reduction of poverty? What is the role of the pattern of growth in the development process? What is the influence of pro-poor and pro-growth policies to reduce poverty? Does one policy application excludes the other?

In order to answer above research questions, it is important to re-examine historical growth path and place the distributional aspect back at the heart of economic analysis. Due to furthure studies should be based on the poverty cycle and interdependence of business cycles and the cycle of poverty. However, emphasis should be placed also on multidimensional measure of poverty.

A unified endogenous approach to the issue and pro-active role of the state based on a hybrid approach, pro-growth and pro-poor policy in the present circumstances, when more than 2.5 billion people in the world are poor, becomes a necessity.

The remainder of the paper is organized as follows: Introduction defines some relative knowledge; Section 1 presents a brief review of literature; in Section 2 emphases has been placed on the sustainability of the "trickle-down" hypothesis; Section 3 speaks in favour of the application of policies to reduce poverty, the last Section contains some concluding remarks and policy recommendations.

\section{Literature review}

Traditional theories of growth have observed separately the phenomena of economic growth and poverty. However, with the performance of market anomalies, it became evident that neoclassical doctrine that prevailed at that time did not find solutions that through its theories and tools explain the complex process of economic growth, and was inadequate in formulating proposals of economic policy.

With a significant increase in regional and intraregional economic and social inequality of the 80s onwards, it became clear that it is not possible to study growth without taking into account the poverty of nations.

Some recent studies are based on endogenous approach and connect the two phenomena, but there is still no achieved consensus in this area. One of main reasons is the complexity of the issue, and inadequate methodological exploration of the topic.

Controversial issue is based basically on two approaches. The first approach is based on the pioneer works of Kuznets (1955), Rostow (1960), Kaldor $(1956,1966)$, and others that place an emphasis on the trickle-down approach (growth will automatically "spill over 
onto" the poor). The second approach i.e. the endogenous approach, re-examines Kuznets's intervention curve, and speaks in favour of the fact that economic growth does not automatically "trickle down" to the poorest as is shown Chenery et al. (1974), Kakwani (1993), Easterley (2000), Bourguignon (2003), Fosu (2010), and others.

A newer approach has been expanded to more subtle studies, such as Bourguignon's (2004), "the poverty-growth-inequality triangle" and some others.

According to Kuznets's inverted U hypothesis (1955), in the earlier stages of development, primarily at middle-income levels, income inequality would grow until a turning point would have been reached, when the distribution of income would become more even again and poverty would rapidly disappear under the influence of the larger size of the cake and fairer distribution. Kuznets's hypothesis is associated with the migration of population from rural to urban sectors.

Piketty (2014) clarifies that Kuznets's idea was that inequalities increases in the early phases of industrialization because only a minority is benefited from the new wealth creation brought by the industrialization process. Later, in more advanced phases of development, inequality automatically decreases as a larger and larger fraction of the population participates in the fruits of the economic growth.

Furthermore, phase growth paradigm developed by W. Rostow (1960) assumes that in the initial phases, in which basic preconditions for growth are created, are very difficult; but once the various elements are aligned and completed, the economy will be able to begin its take-off.

Nurkse's basic thesis (1953) on the system of useful or vicious circuits was based on the concept that poor people are poor because they are malnourished or illiterate, and they are malnourished and illiterate because they are poor. In the same way, countries are poor because they have low savings and investments and they have low savings and investments because they are poor.

In recent decades, due to impressive growth of imbalances in financial and real sector, the growing gap between rich and poor, doubts in "trickle-down" theory have risen. According to Piketty (2014) economists for far too long have neglected the distribution of wealth partly because of Kuznets's optimistic conclusion and partly because of the professional enthusiasm for simplistic mathematical models based on the so-called representative agents.

Ferreira, Leite and Ravallion (2010) in their research observing one of fastest growing world's economies - Brazil pointed out the fact that for over the last two decades, disappointingly, the low rates of poverty reduction in Brazil were not exclusively due to its low rate of economic growth. The investigations also reflected a low growth elasticity of poverty reduction that was consistent with the country's high level of inequality. The sectoral and geographic pattern of growth and the limited initial ability of the poor to participate in and to benefit from it are very important.

In the case of China and India - two economies that account for a third of the world's population Quah (2003) concludes that aggregate economic growth might well come about only with increases in inequality. However, given the magnitudes that are historically reasonable, growth is unambiguously beneficial - especially for the poor in general, and even for the poor in particular, when inequality rises. 
Fosu (2010) presents recent global evidence on the transformation of economic growth to poverty reduction in developing countries, with emphasis on the role of income inequality. He found that on average income growth has been the major driving force behind both the declines and increases in poverty. However, the study also documents substantial regional and country differences. While in the majority of countries, growth was the major factor behind decreasing or increasing poverty and inequality. Nevertheless, it played the crucial role in poverty behaviour in a large number of countries. The current results suggest that adopting appropriate pro-poor growth strategies require some understanding of idiosyncratic attributes. The study finds that there are substantial differences in the abilities of countries to translate economic growth to poverty reduction based on their respective inequality and income profiles. Understanding such country-specific profile is crucial in crafting policies for achieving poverty reduction most effectively and globally.

Bourguignon's (2003) approach is quite independent of the phenomenon based on previous literature, according to which growth would tend to be faster in a less inegalitarian environment. Actually, he stands between two approaches. The first one is based on linear regressions where the evolution of poverty measure is explained by the growth of income or GDP per capita and a host of the other variables; for instance Ravallion and Chen (1997), Dollar and Kray (2002) and others. On the other hand second approach takes into account the poverty/mean/income distribution identity. Also, their analysis is generally restricted to a specific country or to a limited number of countries or regions; for instance Datt and Ravallion (1992), Kakwani (1993) and some others. Bourguignon points out that international comparison in the evolution of poverty should all rely on the methodology based on poverty/mean-income/distribution identity. He demonstrates that a permanent redistribution on income reduces poverty through "distribution effect", but it also contributes to a permanent increase in the elasticity of poverty reduction with respect to growth. The level of development and the degree of inequality influence the speed by which economic growth reduces poverty. The growth poverty relationship is not simple and corresponding elasticity differ across region and countries.

Conclusions regarding the nexus between poverty and economic growth vary among different periods, countries and authors. Also, it is important to note that the way in which the poverty is measured, or the nature of poverty is analyzed, influences the conclusion of the interdependence of phenomena and the concepts of the very policies against poverty. Foster and Szekely (2001) state how, for example, Ravallion (2000) employs absolute poverty standards of $\$ 1$ and $\$ 2$ a day to identify the poor and then aggregates using the most common measures of poverty, the headcount ratio and the per capita poverty trap. Whereas Dollar and Kray (2002) employ a purely relative definition of the poor as persons in the lowest fifth of the distribution and then aggregate by using the most common indicator or relative affluence, the per capita income of this group.

A chronological review of previous theoretical research and empirical studies can be presented as in the Table 1. 
Table 1. Previous theoretical research

\begin{tabular}{|c|c|c|}
\hline Year & Author & Theoretical approach \\
\hline 1953 & Nurkse, R. & System of useful or evil circles \\
\hline 1955 & Kuznets, S. & Kuznets' inter-binding U-curve \\
\hline 1960 & Rostow, W. & Rostow's upswing phase \\
\hline 1956,1958 & Kaldor, N. & Growth, Poverty, Inequality \\
\hline 1974 & Chenery, H. et al. & $\begin{array}{l}\text { Redistribution with growth; policies to improve } \\
\text { income distribution in developing countries }\end{array}$ \\
\hline 1992 & Datt, G. and Ravallion, M. & Effects of inequality and income on poverty \\
\hline 1994 & Alesina, A. and Rodrik, D. & Distributive policies and economic growth \\
\hline 1994 & Person, T. and Tabellini, G. & Inequality and Growth \\
\hline 1983,1999 & Sen, A. & Development, Poverty and Economic Growth \\
\hline 2001 & Hoff, K. and Stiglitz, E. & $\begin{array}{l}\text { Modern Economic Theory, Poverty, Growth } \\
\text { and Inequality }\end{array}$ \\
\hline 2001 & Meier, G. & $\begin{array}{l}\text { Pattern of Growth, Income distribution and } \\
\text { poverty }\end{array}$ \\
\hline 2001 & Yusuf, S. and Stiglitz, J. & Development and Growth \\
\hline 2004 & Bourguignon, $\mathrm{F}$. & The Poverty Growth-Inequality Triangle \\
\hline 2005 & Azariadis, C. and Stachurski, J. & $\begin{array}{l}\text { Models and Mechanism that cause poverty } \\
\text { to persist }\end{array}$ \\
\hline 2007 & Jenkins, S. and Micklewright, J. & Inequality and Poverty Re-examined \\
\hline 2003,2008 & Chang, H. J. & Rethinking Development Economics \\
\hline 2011 & Fosu, A. K. & $\begin{array}{l}\text { Growth, Inequality, and Poverty Reduction } \\
\text { in Developing Countries }\end{array}$ \\
\hline 2012 & Mosley, P. & Poverty reduction and growth \\
\hline 2012 & Stiglitz, J. & Inequality and growth \\
\hline 2005 & Banerjee, A. et al. & Poverty and rate of returns \\
\hline 2012 & Banerjee, A. and Duflo, E. & Poor Economics \\
\hline 2013 & Manda, D. K. & Revisiting growth, inequality and poverty nexus \\
\hline 2013 & Thorbecke, E. & Growth, Inequality-Poverty Nexus \\
\hline 2014 & Piketty, T. & Economic Inequality, Growth, Capitalism \\
\hline 2013 & Sharma, S. & $\begin{array}{l}\text { The role of community in socio-economic } \\
\text { development }\end{array}$ \\
\hline 2013 & Zaman, K. and Khilji, B. A. & "Growth Inequality Poverty Triangle" \\
\hline 2014 & Zaman, K. et al. & "Poverty Equivalent Growth Rate" \\
\hline 2014,2012 & Galbraith, J. & $\begin{array}{l}\text { The Great Crisis and the Future of Growth, } \\
\text { Inequality and Instability }\end{array}$ \\
\hline 2015 & Aguiar, M. and Bils, M. & Consumption and Income Inequality \\
\hline 2015 & Jones, C. I. & $\begin{array}{l}\text { Pareto and Piketty: The Macroeconomics of Top } \\
\text { Income and Wealth Inequality }\end{array}$ \\
\hline 2015 & Blume, L. E. and Sargent, T. J. & Harrod 1939 \\
\hline
\end{tabular}

Source: Authors. 
As it can be seen from the table above, the theoretical approaches develop a number of models that analyze the role of growth vs. poverty.

The empirical section usually consists of an analysis of a panel data from a large set of countries to identify the relationship between economic growth and poverty (see Table 2).

Table 2. Previous empirical studies

\begin{tabular}{|c|c|c|c|}
\hline Year & Author & Sample countries & Results \\
\hline 1979 & $\begin{array}{l}\text { Ahluwalia, M. } \\
\text { et al. }\end{array}$ & 36 & $\begin{array}{l}\text { Cross-country analysis indicate that elimination } \\
\text { of absolute poverty by the end of the century } \\
\text { is a highly unlikely prospect, even to achieve a } \\
\text { substantial reduction will require a combination } \\
\text { of policies designed to accelerate the growth } \\
\text { of poor countries, to distribute the benefits of } \\
\text { growth more equitably, and to reduce population } \\
\text { increase. }\end{array}$ \\
\hline
\end{tabular}

\begin{tabular}{lll}
\hline $1994 \begin{array}{l}\text { Person, T. } \\
\text { and } \\
\text { Tabellini, G }\end{array}$ & 9 & $\begin{array}{l}\text { Historical panel data and cross-section analysis } \\
\text { indicates a significant and substantial negative } \\
\text { relation between inequality and growth. }\end{array}$ \\
\hline $1997 \quad$ Ravallion, M. & 23 & $\begin{array}{l}\text { Household survey data for developing countries } \\
\text { suggest that the initial distribution does matter } \\
\text { to how much the poor share in rising average } \\
\text { incomes; higher initial inequality tends to reduce } \\
\text { the impact of growth on absolute poverty. }\end{array}$ \\
\hline $1997 \quad \begin{array}{l}\text { Ravallion, M } \\
\text { and Chen, S. }\end{array}$ & $\begin{array}{l}\text { Using household survey data analysis indicates } \\
\text { that changes in inequality and polarization were } \\
\text { uncorrelated with changes in average living } \\
\text { standards. Almost always, poverty fell with the } \\
\text { growth in average living standards and rose with } \\
\text { contraction. }\end{array}$ \\
& &
\end{tabular}

1998 Deininger, K They have assembled and Squire, L. a data set on income inequality that contains at least one observation of the Gini index for 108 countries and information on shares received by different quintiles of the population from 103 countries. There are 54 countries with four or more observations and 32 countries with eight or more observations.
Regression analysis (cross-country data) indicate that there is a strong negative relationship between initial inequality, inequality in the asset distribution and long-term growth; inequality reduces income growth for the poor, but not for the wealthy; available data provide little support for the Kuznets hypothesis. Policies that increase aggregate investment and facilitate the acquisition of assets by the poor might thus be doubly beneficial for growth and poverty reduction.

Evidence from a broad panel of countries shows that higher inequality tends to retard the growth in poor countries and encourage growth in richer places. Income - equalizing policies might be justified on growth promotion grounds in poor countries. For richer countries, active income redistribution appears to involve a tradeoff between the benefits of greater inequality and a reduction in overall economic growth. 
Continue of Table 2

\begin{tabular}{|c|c|c|c|}
\hline Year & Author & Sample countries & Results \\
\hline 2001 & $\begin{array}{l}\text { Foster, J. E. and } \\
\text { Szekely, M. }\end{array}$ & 20 & $\begin{array}{l}\text { Empirical analysis estimates growth elasticity } \\
\text { over the last quarter century. They find that the } \\
\text { growth elasticity of bottom sensitive general } \\
\text { means is positive but significantly smaller than } \\
\text { one. This suggests that the incomes of the poor } \\
\text { do not grow one-for-one with increases in } \\
\text { average income. }\end{array}$ \\
\hline
\end{tabular}

\begin{tabular}{lll}
\hline 2002 Dollar, D. and & 92 & Cross-country analysis indicates that the poor \\
Kraay, A. & benefit from aggregate economic growth, but \\
& this does not imply that growth is all that is \\
& needed to improve the lives of the poor. Growth \\
& enhancing policies of good rule of law, fiscal \\
& discipline, and openness to international trade \\
& should be at the center of successful poverty \\
& reduction strategies.
\end{tabular}

\begin{tabular}{llll}
\hline 2002 & $\begin{array}{l}\text { Datt, G. } \\
\text { and } \\
\text { Ravallion, M. }\end{array}$ & 1 & $\begin{array}{l}\text { Regression analysis indicates that income } \\
\text { growth is one of an effective strategy for poverty } \\
\text { reduction in India. }\end{array}$ \\
\hline 2003 & Quah, D. & 2 & $\begin{array}{l}\text { Arithmetic approach indicates that growth } \\
\text { is unambiguously beneficial - especially for } \\
\text { the poor in general, and even for the poor in } \\
\text { particular when inequality rises. }\end{array}$
\end{tabular}

\begin{tabular}{|c|c|c|}
\hline $\begin{array}{l}\text { 2003, Bourguignon, F. } \\
2004\end{array}$ & 26 & $\begin{array}{l}\text { Using cross-sectional data analysis indicates } \\
\text { that level of development, degree of inequality, } \\
\text { influence the speed by which economic growth } \\
\text { reduces poverty. Growth poverty relationship } \\
\text { is not simple and the corresponding elasticity } \\
\text { is certainly not constant across countries and } \\
\text { across the various ways of measuring poverty. }\end{array}$ \\
\hline
\end{tabular}

2004 Salvatore, P. $\quad$ _ $\quad$ Regression analysis indicates that inequality
in income distribution among the poor can increase poverty despite good growth prospects.

\begin{tabular}{|c|c|c|c|}
\hline 2008 & Barro, R. J. & 100 & $\begin{array}{l}\text { A cross-country analysis shows that the Kuznets } \\
\text { curve is reasonably stable from } 1960 \text { through } \\
\text { the } 2000 \text { s. However, these curves do not explain } \\
\text { the bulk of the observed variation in income } \\
\text { inequality across countries or over time. }\end{array}$ \\
\hline 1993 & Kakwani, N. & 1 & $\begin{array}{l}\text { The paper explores the relation between } \\
\text { economic growth and poverty, and develops the } \\
\text { methodology to measure separately the impact } \\
\text { of changes in average income and income } \\
\text { inequality on poverty. }\end{array}$ \\
\hline 2003 & Kakwani, N. & 3 & $\begin{array}{l}\text { The paper proposes a pro-poor growth measure } \\
\text { that satisfies the monotonicity criterion. } \\
\text { This measure is called a "poverty equivalent } \\
\text { growth rate" which takes into account both } \\
\text { the magnitude of growth and how the benefits } \\
\text { of growth are distributed to the poor and the } \\
\text { non-poor. It is indicative that to achieve rapid } \\
\text { poverty reduction the poverty equivalent growth } \\
\text { rate, rather than the actual growth rate should be } \\
\text { maximized. }\end{array}$ \\
\hline
\end{tabular}


End of Table 2

\begin{tabular}{|c|c|c|c|}
\hline Year & Author & Sample countries & Results \\
\hline 2010 & Fosu, K. & 16 & $\begin{array}{l}\text { Study examined the extent to which inequality } \\
\text { influences the effectiveness of income growth } \\
\text { in poverty reduction. Cross section study finds } \\
\text { that the responsiveness of poverty to income is } \\
\text { a decreasing function of inequality. The results } \\
\text { also imply a significant variation across African } \\
\text { countries. }\end{array}$ \\
\hline 2010 & Fereira, F. & 1 & $\begin{array}{l}\text { Paper indicates that Brazil's disappointingly low } \\
\text { rate of poverty reduction during } 1980-2000 \text { was } \\
\text { not only to weak economic growth. Though it } \\
\text { was certainly key. It also reflected a low growth } \\
\text { elasticity of poverty alleviation consistent with } \\
\text { the country's high level of inequality. }\end{array}$ \\
\hline 2011 & $\begin{array}{l}\text { Škare, M. } \\
\text { and Pržiklas } \\
\text { Družeta, R. }\end{array}$ & 3 & $\begin{array}{l}\text { Var and cointegration approach indicates that } \\
\text { economic growth is good for poverty but not } \\
\text { by default. Growth is essential but not sufficient } \\
\text { condition for poverty alleviation. }\end{array}$ \\
\hline 2012 & Mulok, D. et al. & 1 & $\begin{array}{l}\text { Using time series data, the results show that } \\
\text { economic growth is necessary but not sufficient } \\
\text { for poverty alleviation. }\end{array}$ \\
\hline 2013 & Thorbecke, E. & 6 & $\begin{array}{l}\text { Cross-country analysis indicates that high } \\
\text { inequality and low growth has been a major } \\
\text { obstacle to the achievement of poverty } \\
\text { reduction. }\end{array}$ \\
\hline 2014 & Anand, R. et al. & 1 & $\begin{array}{l}\text { They exploit the methodology of Datta and } \\
\text { Ravallion } 1992 \text { in examining the role of growth } \\
\text { and equity in poverty reduction. Robust } \\
\text { economic growth has been a major driver of } \\
\text { poverty alleviation and inclusiveness in India. }\end{array}$ \\
\hline 2014 & Zaman, K. et al. & 1 & $\begin{array}{l}\text { A } 21 \text { household survey reveals that despite the } \\
\text { positive signs in agriculture growth, the growth } \\
\text { process may not be classifiable as pro-poor. }\end{array}$ \\
\hline 2015 & $\begin{array}{l}\text { Ribeiro, A. P. } \\
\text { et al. }\end{array}$ & 24 & $\begin{array}{l}\text { Results show that a multidimensional poverty } \\
\text { concept is relevant for assessing deprivation } \\
\text { in developed countries and that in line } \\
\text { with the relevant literature, the dynamics of } \\
\text { some macroeconomic variables is crucial to } \\
\text { deprivation performances. }\end{array}$ \\
\hline
\end{tabular}

Source: Authors.

Despite previous research, empirical evidence is still lacking and it can be conclude that we know very little about the nature of economic growth and the poverty. Such conclusion is also confirmed by insufficient studies in the area of the cycle of poverty, causes and pattern of economic growth and especially of business cycles and poverty. 


\section{Data analysis}

\section{Is there trickle-down? The ignorance hypothesis}

By reviewing the relationship between economic growth rates in the countries of the world and their poverty rates, in a scatter diagram, one can quickly spot the positive causality between the two phenomena (poverty declines as growth rates grow). But then how to explain that in the last 100 years there had been continuous economic growth but also an increase in poverty? Is according the specified the causality of phenomenon excluded? Is reducing poverty a function of growth?

As this example illustrates action to attack poverty must be based on understanding of what has caused this occurrence. Given the fact that over the last decade poverty has evolved in different ways, it is essential to gain an insight into the pattern of poverty and the pattern of economic growth.

Lack of knowledge and denial of the nature of economic growth can lead to growing cycles and crises and will deepen poverty (Fig. 1). As a support of the above fact is the growth experience of the 1960s and the 1970s, when during growth an increase in unemployment and poverty occurred. Accordingly, it is logical to conclude that economic growth is the engine of poverty reduction, but it seems to work much more efficiently in certain conditions than in others (as confirmed by tables below).

1) Under different conditions, similar rates of growth can have very different effects on poverty (Table 3 ).

2) Economic growth is good for the poor even when inequality increases (Table 4).

To sum up, Table 3 points to considerable regional differences regarding the effects of GDP growth on poverty reduction. Under different condition, similar rates of growth can have very different effects on poverty.

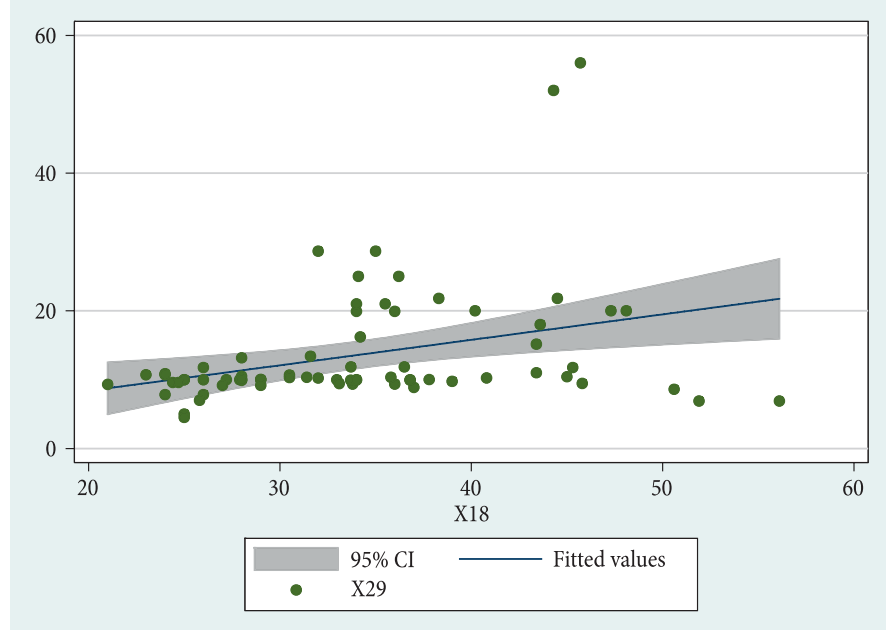

Fig. 1. The regression line of poverty rate and economic growth Source: Author's making. 
Fosu (2010) states that EAP (East Asia and Pacific) registered spectacular GDP growth per capita, resulting in substantial poverty reductions over both sub-periods. Unlike the example of SAS (South Asia) countries that despite high GDP growth have managed to reduce poverty in only relatively modest proportions. Furthermore, the moderate GDP growth in MENA (Middle East and North Africa) was transformed to appreciable poverty declines during the early sub-period, but the stronger growth in the latter period resulted in only modest poverty reduction.

According to Fosu (2010), lower income and higher income countries exhibited greater abilities to transform a given growth rate to poverty reduction. Such countries would also enjoy larger inequality elasticities, suggesting that inverting inequality would be more deleterious to poverty in these countries than in their low-income counterparts. On the contrary, low-income countries would conversely require greater efforts in both income growth and decreases in inequality to reduce their poverty levels.

It is visible from the Table 3 that for poverty alleviation it is critical to know the pattern of growth and the nature of economic growth. Denying these assumptions may result in inappropriate economic policy, and the demolition of the balance and the presence of market anomalies.

According to Table 4, the data indicate that growth is good for the poor even when inequality is rising.

Table 3. Per capita GDP growth vs. Poverty reduction by region, 1981-2005

\begin{tabular}{lcccccc}
\hline & $\begin{array}{c}\text { P.C. GDP } \\
\text { growth }\end{array}$ & $\begin{array}{c}\text { P.C. GDP } \\
\text { growth }\end{array}$ & $\begin{array}{c}\$ 1.25 \text { Po } \\
\text { growth }\end{array}$ & $\begin{array}{c}\$ 1.25 \text { Po } \\
\text { growth }\end{array}$ & $\begin{array}{c}\text { \$2.50 Po } \\
\text { growth }\end{array}$ & $\begin{array}{c}\text { \$2.50 Po } \\
\text { growth }\end{array}$ \\
\hline $\begin{array}{l}\text { Region/ } \\
\text { Variable-Period }\end{array}$ & $1981-95$ & $1996-05$ & $1981-96$ & $1996-05$ & $1981-96$ & $1996-05$ \\
\hline $\begin{array}{l}\text { East Asia and Pacific } \\
\text { (EAP) }\end{array}$ & 6.894 & 6.355 & -5.126 & -8.481 & -1.616 & -4.331 \\
\hline $\begin{array}{l}\text { Eastern Europe and } \\
\text { Central Asia (EECA) }\end{array}$ & -3.434 & 4.138 & 6.769 & $-2.594 \mathrm{~h}$ & 1.229 & -3.911 \\
\hline $\begin{array}{l}\text { Latin America and } \\
\text { Caribbean (LAC) }\end{array}$ & 0.140 & 1.394 & -1.083 & -3.176 & -0.605 & -2.538 \\
\hline $\begin{array}{l}\text { Middle East and North } \\
\text { Africa (MENA) }\end{array}$ & 0.713 & 2.309 & -4.347 & -1.445 & -1.215 & -1.484 \\
\hline South Asia (SAS) & 3.208 & 4.143 & -1.548 & -1.710 & -0.296 & -0.530 \\
\hline Sub- Saharan Africa (SSA) & -1.009 & 1.293 & 0.644 & -1.597 & 0.270 & -0.517 \\
\hline
\end{tabular}

Source: Fosu (2011: 34).

Table 4. Aggregate income and population dynamics, China, India and the US

\begin{tabular}{|c|c|c|c|c|c|}
\hline \multirow[t]{2}{*}{ Countries } & \multicolumn{2}{|c|}{ Per capita incomes (US\$) } & & \multicolumn{2}{|c|}{ Population $\left(\mathrm{x} 10^{6}\right)$} \\
\hline & 1980 & 199 & & 1980 & 1992 \\
\hline China & 972 & 1493 & 3.58 & 981 & 1162 \\
\hline India & 882 & 1282 & 3.12 & 687 & 884 \\
\hline USA & 15295 & 17945 & 1.33 & 228 & 255 \\
\hline
\end{tabular}

Source: Quah (2003). 
Namely, Quah (2003) on the example of India and China (two economies that account for a third of the world's population and today's fast-growing economy) shows how growth is unambiguously beneficial - especially for the poor in general, and even for the poor in particular when inequality rises.

According to Quah, Table 4 records that between 1980 and 1992 China's per capita income grew from US\$972 to US\$1493 at an annual growth rate of 3.58. India grew at a lower annual rate of $3.12 \%$ increasing its per capita income from US\$882 to US\$1282.

Table 5 shows that China's fast-increasing per capita income came together with rises in inequality. Inequality in China, measured by Gini coefficient increased from 0.32 to 0.38 while that in India remained constant at 0.32 . From the experience of the three countries it can be concluded that in a fast growing economy inequality also rises rapidly.

Furthermore, in India inequality remained constant, and since the total Indian population also increased it could have been expected that the poor will increase in number, but Table 6 shows that it did not happen.

Quah claims that between 1980 and 1992 the number of Indians living on less than US\$2 a day fell from 326-426 $\mathrm{m}$ to less than a half of that, $110-166 \mathrm{~m}$. India reduced the population living in the very poor income range by about a quarter of a billion.

Based on the Quah's research it is visible how even despite the positive relation between growth and inequality, the world's poor benefited dramatically from economic growth. Quah concludes that given the historical experience in China and India, aggregate economic growth might well come about only with an increases in inequality (see Table 7).

Table 5. Inequality in China, India, and the US, by Gini coefficient (from Deininger and Squire, 1996)

\begin{tabular}{cccc}
\hline \multirow{2}{*}{ Country } & \multicolumn{3}{c}{ Gini coefficient } \\
\cline { 2 - 4 } & 1980 & 1992 & Min (year) \\
\hline China & 0.32 & 0.38 & $0.26(1984)$ \\
\hline India & 0.32 & 0.32 & $0.30(1990)$ \\
\hline USA & 0.35 & 0.38 & $0.35(1982)$ \\
\hline
\end{tabular}

Source: Quah (2003).

Table 6. Fraction of population and number of people with incomes less than US\$ per day

\begin{tabular}{ccc}
\hline \multirow{2}{*}{ Country } & \multicolumn{2}{c}{$\mathrm{Y}=2 ; \mathrm{HC}^{y}\left(\mathrm{P}^{y}, 10^{6}\right)$} \\
\cline { 2 - 3 } & 1980 & 1992 \\
\hline China & $0.37-0.54(360-530)$ & $0.14-0.17(158-192)$ \\
\hline India & $0.48-0.62(326-426)$ & $0.12-0.19(110-166)$ \\
\hline
\end{tabular}

Source: Quah (2003).

Table 7. From 1980's perspective

\begin{tabular}{ccc}
\hline Country & Gini coefficient, $\mathrm{P}$ constant: $-\mathrm{P}^{y}$ & $\mathrm{HC}^{y}$ constant: Gini k/ Gini k \\
\hline China & 33 million/year & $8.3 \%$ per year \\
\hline India & 17 million/year & $8.8 \%$ per year \\
\hline
\end{tabular}

Source: Quah (2003). 
However, given the magnitudes that are historically reasonable, growth is unambiguously beneficial - especially for the poor in general, and even for the poor, in particular, when inequality rises.

\section{Pro-poor economic growth}

The effect of income growth in reducing poverty has received significant attention in the search for pro-poor growth. There is no doubt that growth is the engine of poverty reduction, but as we have seen how its effects seem to work much more different in some regions than in others. The variance in poverty rates supports the view that growth may be necessary but not sufficient for maximum poverty reduction.

Today at the beginning of the twenty-first century, despite continued economic development since 19th century and breaking of the vicious circle helped by the industrial revolution, one third of the world population is still poor.

Sharma (2013:3) points out that from the point of the much maligned 19th century, the century of newly rich and the triumphant bourgeoisie, was the harbinger of a new destiny for civilizations and human personality. The great problem of the future will be to create a mass civilization of high quality, which is unthinkable without substantially large surpluses devoted to the well-being of the society.

So the question arises: What factors cause such variations in poverty? Which factor must we take into account in order to design appropriate pro-poor growth policies?

As a response to the question, it is necessary to point out that there are still transverse opinions and debates are still open. In the following discussion we can look back to the literature review that leads us to the factors that must be considered when designing appropriate pro-poor growth policies.

USAID (2005) suggests that balancing strategies to promote growth and to achieve greater equality are the key to poverty eradication (Bogunović 2001). Policy areas can be identified that are able to spread incomes more evenly, while accelerating growth through: expanding basic educational opportunities, expanding access to quality primary health care and combating communicable diseases, reducing biases against agricultural, reforming trade, limiting taxes and labour market regulations that raise labour costs unduly, improving the poor's access to credit and land and other natural resources, promoting development policies that address the direct links among poverty, inequality, and violent conflict in post-conflict environments, vigorously combating HIV/AIDS, promoting public workfare programs and the provision of social safety nets in cases of transient poverty caused by crises.

According to Meier and Stiglitz (2001) with over than 1.2 billion people living on less than a dollar a day, it becomes clear that trickle-down theory must be supplemented by policies of inclusion that lessen sharp disparities in incomes and assets, enhance human capital accumulation and employment opportunities, and help in providing safety nets for the more vulnerable elements of a society. Furthermore, the authors state that successful development policies need to be determined not only by how more rapid growth or real 
income can be generated, but also by how real income can be used to achieve other values incorporated in "development". So, for a better understanding of the role of income distribution in the process of development, emphasis should be put on "quality of growth" or a desired pattern of growth.

Kralješević (2014) argues that economists have been disloyal to the fundamental starting points and principles, by disregarding the importance of freedom which was essential for its emancipation and market as its key criterion of choice.

Easterley and Serven (2003) stress how the region's wide gaps in infrastructure implied significant lost opportunities in growth and welfare.

Lopez (2006) analyses that fast poverty reduction in the region would require the implementation of development strategies that simultaneously aim at achieving quick sustained growth rates and more equal societies. Referring to the problem of insufficient growth in developing countries, the author points out that we should first focus on how to achieve growth and then only consider how to ensure that its pattern is pro-poor.

Perry et al. (2006) pointed out that besides the accent should be put on the composition of growth in order to reduce poverty, government may need to adopt complementary policies behind the border - facilitating access to education, expanding infrastructure to lagging areas with the potential to tap into the benefits of liberalization, and offering conditional transfers for poor peasants who may lose out in the transition. These complementary policies can mitigate the inequality effects while considerably enhancing the growth effects, permitting the country to take full advantage of the opportunities brought about by trade opening.

According to Ravallion (2007) more rapid poverty reduction requires more growth, a more pro-poor pattern of growth, and success in reducing the antecedent inequalities that limit poor people's economic opportunities.

Štreimikiene and Barakauskaite-Jakubauskiene (2012) pointed out that healthy and satisfied with the quality of life nation have positive impact on stable economic growth.

More chronological review of previous empirical studies on economic policy and growth can be seen in Perry et al. (2006: 77) and Zaman et al. (2014: 715) and in others.

It can be concluded with certainty that applying pro-poor growth policy represents a great challenge for the future as indicated by the figure below. In Figure 2 it is evident that when the goals of growth change from Real GDP p.c. towards realization of HDI, reducing poverty, achieving rights and capabilities, freedoms, achieving sustainable growth, so do the policies for accomplishing these goals change as well.

Namely, initially in the 1950s the awareness of disparities was seen as a normal occurrence and the policy and according to Nurkse (1953) the main reason why country is poor is the lack of accumulated capital.

By developing new theories, it was learned that only with the assumption of institutional pre-conditions with the choice of appropriate policies and the choice of sector investments that have the greatest multiplier effect on the overall economy, it is possible to make a major developmental impact (big push) and thus make poverty soluble in a dynamic process of growth and development (Bogunović 2001). 


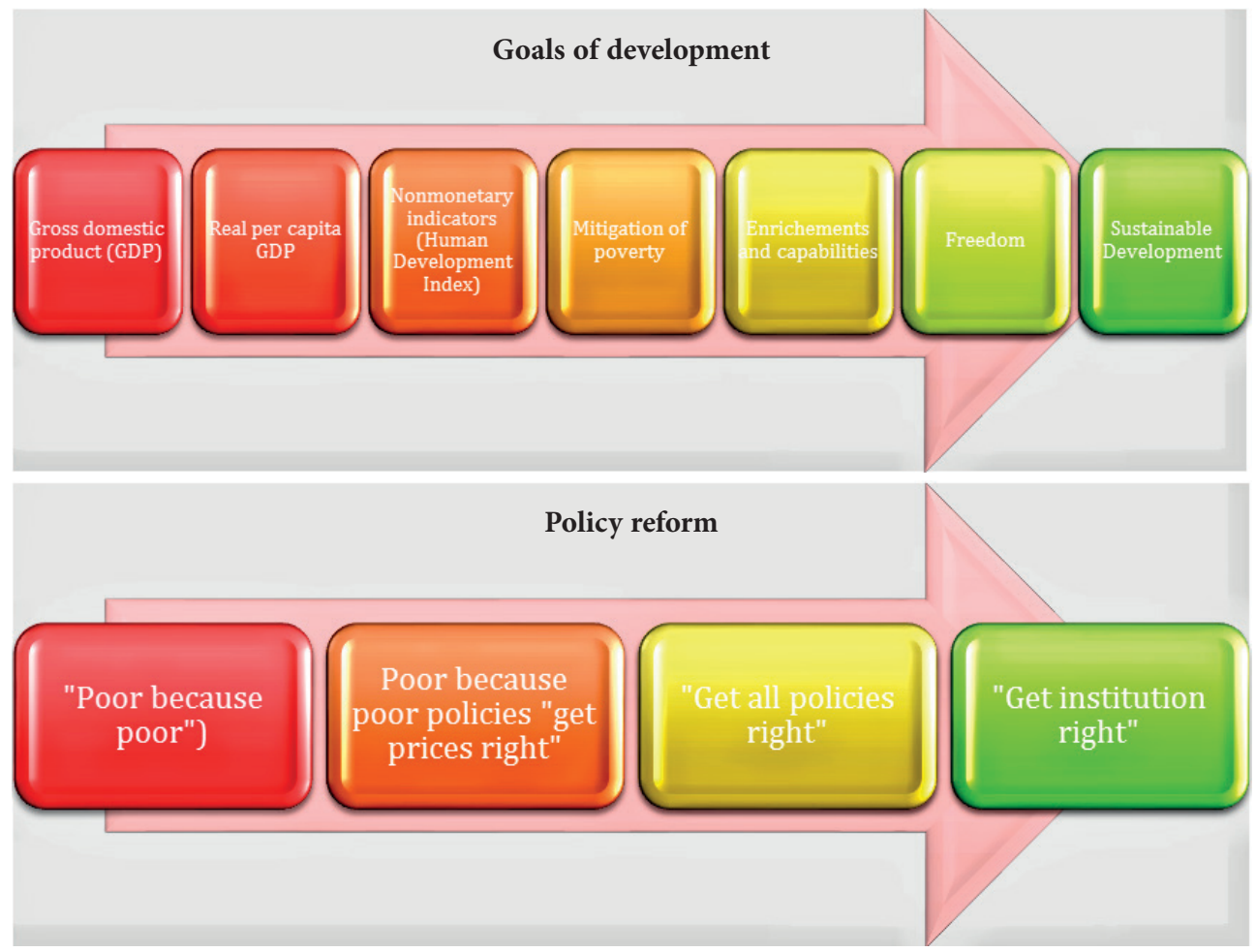

Fig. 2. The evolution of development thought Source: Meier, Stiglitz (2001: 3).

Thus, economic growth by itself is not a sufficient condition for poverty alleviation. Such growth is simply not sustainable. However, in order to make growth sustainable, initially it is necessary to know the nature of growth and to know the answers to such questions as: What are the sources of growth? How can macroeconomic stability be sustained? What are the forces that can explain the divergence in incomes across countries?

Due to, we should change our world view. As Chen (2002) and Zolfani et al. (2013) pointed out The Ying-Yang principle that embodies duality, paradox, unity in diversity change and harmony, offering a holistic approach to problem solving is needed.

Although substantial progress has been made, however, there is still too much left to explain about development policy-making.

\section{Conclusions}

In most cases where growth occurs, poverty falls no matter whether inequality becomes greater or lesser. This is best indicated in the example of emerging countries like India and China. Furthermore, since similar growth rates impact differently on poverty reduction, we may conclude that growth is good for the poor, but it is not enough (essential but not sufficient condition for poverty alleviation). 
Growth by itself may not be long-lasting and sustainable. It is therefore essential to base the strategy of poverty reduction on rapid but sustained economic growth. The extent to which growth reduces poverty depends upon how we measure poverty, on absorptive capacity of the poor, the pace and pattern of the growth.

Today, as billions of people still live in poverty, the most important challenge for policy makers is to ensure institutional pre-conditions and to combine pro-growth and pro-poor policies that will enable the poor to participate in the opportunities and to contribute to future growth.

Given the crisis in the financial and real sector, global recession, increasing unemployment and inequality, future studies besides reviewing the "trickle-down" theory and especially its effect on lower income groups, should be based on the study of the cycle of poverty and interdependence of business cycles and the cycle of poverty. However it is of great importance to review a new unique poverty measure.

This paper represents our modest contribution to the analysis of interdependence of poverty and economic growth, and can serve as the basis for future research.

\section{Acknowledgements}

This work has been fully supported by the Croatian Science Foundation under the project number 9481 "Modelling Economic Growth - Advanced Sequencing and Forecasting Algorithm". Any opinions, findings, and conclusions or recommendations expressed in this material are those of the author(s) and do not necessarily reflect the views of Croatian Science Foundation.

\section{References}

Adams, R. H. 2004. Economic growth, inequality, and poverty: estimating the growth elasticity of poverty, World Development 32(12): 1989-2014. http://dx.doi.org/10.1016/j.worlddev.2004.08.006

Aguiar, M.; Bils, M. 2015. Has consumption inequality mirrored income inequality?, American Economic Review 105(9): 2725-2756. http://dx.doi.org/10.1257/aer.20120599

Ahluwalia, M.; Carter, N. G.; Chenery, H. 1979. Growth and poverty in developing countries, Journal of Development Economics 6(3): 299-341. http://dx.doi.org/10.1016/0304-3878(79)90020-8

Alesina, A.; Rodrik, D. 1994. Distributive politics and growth, Quarterly Journals of Economics 109(2): 465-490. http://dx.doi.org/10.2307/2118470

Anand, R.; Tulin, V.; Kumar, N. 2014. India: defining and explaining inclusive growth and poverty reduction, IMF Working Paper WP/14/63, Washington.

Azariadis, C.; Stachurski, J. 2005. Poverty traps, in P. Aghion, S. Durlauf (Eds.). Handbook of economic growth, Vol. 1A. Amsterdam: Elsevier, 295-284. http://dx.doi.org/10.1016/S1574-0684(05)01005-1

Banerjee, A.; Abhijit, V.; Duflo, E. 2005. Growth theory through the lens of development economics, in P. Aghion, S. Durlauf (Eds.). Handbook of economic growth, Vol. 1A. Amsterdam: Elsevier, 473-552. http://dx.doi.org/10.1016/S1574-0684(05)01007-5

Banerjee, A.; Duflo, E. 2012. Poor economics. London: Penguin Books.

Barro, R. J. 2000. Inequality and growth in a panel of countries, Journal of Economic Growth 5(1): 5-32. http://dx.doi.org/10.1023/A:1009850119329 
Barro, R. J. 2008. Inequality and growth revisited, Working paper on regional economic integration, No. 11. Asian Development Bank.

Blume, L. E.; Sargent, T. J. 2015. Harrod 1939, The Economic Journal 125(583): 350-377. http://dx.doi.org/10.1111/ecoj.12224

Bogunović, A. 2001. Economic integration and regional policy. Ekonomski Fakultet Zagreb, Faculty of Economics, Zagreb: Mikrorad d.o.o.

Bourguignon, F. 2003. The growth elasticity of poverty reduction: explaining heterogeneity across countries and time periods, in T. S. Eicher, S. J. Turnovsky (Eds.). Inequality and growth: theory and policy implications. Cambridge, MA: MIT Press, 3-26.

Bourguignon, F. 2004. The poverty-growth-triangle, Working Paper 125. Indian Council for Research on International Economic Relation.

Chang, H. J. 2003. Rethinking development economics. London: Anthem Press.

Chang, H. J. 2008. Bad Samaritans. London: Random House.

Chen, M. J. 2002. Transcending paradox: the Chinese "middle way" perspective, Asian Pacific Journal of Management 19(2/3): 179-199. http://dx.doi.org/10.1023/A:1016235517735

Chenery, H.; Ahluwalia, M.; Bell, C.; Duloy, J.; Jolly, R. 1974. Redistribution with growth: policies to improve income distribution in developing countries. New York, Oxford: Oxford University Press.

Datt, G.; Ravallion, M. 1992. Growth and distribution components of changes in poverty: a decomposition to Brasil and India in the 1980s, Journal of Development Economics 38(2): 275-295. http://dx.doi.org/10.1016/0304-3878(92)90001-P

Datt, G.; Ravallion, M. 2002. Is India economic growth leaving the poor behind?, Journal of Economic Perspectives 16(3): 89-108. http://dx.doi.org/10.1257/089533002760278730

Deininger, K.; Squire, L. 1996. A new data set measuring income inequality, World Bank Economic Review 10(3): 565-591. http://dx.doi.org/10.1093/wber/10.3.565

Deininger, K.; Squire, L. 1998. New ways of looking at old issues: inequality and growth, Journal of Development Economics 57(2): 259-287. http://dx.doi.org/10.1016/S0304-3878(98)00099-6

Dollar, D.; Kraay, A. 2002. Growth is good for the poor, Journal of Economic Growth 7(3): 195-225. http://dx.doi.org/10.1023/A:1020139631000

Easterley, W.; Serven, L. 2003. The limits of stabilization: infrastructure, public deficit, and growth in Latin America. World Bank, Washington.

Easterley, W. 2000. The effect of IMF and World Bank programs on poverty. Mimeo. World Bank, Washington, D.C.

Ferreira, F. 2010. Distributions in motion: economic growth, inequality, and poverty dynamics. Working paper series, ECINEQ, 2010-183.

Ferreira, F.; Leite, P. G.; Ravallion, M. 2010. Poverty reduction without economic growth? Explaining Brasil's poverty dynamics, 1985-2004, Journal of Development Economics 93(1): 20-36. http://dx.doi.org/10.1016/j.jdeveco.2009.06.001

Foster, J. E.; Szekely, M. 2001. Is economic growth good for the poor? Tracking low incomes using General Means, Working Paper 453. American Development Bank, Washington N.Y.

Fosu, A. K. 2011. Growth, inequality, and poverty reduction in developing countries, Working Paper No. 2011/01, UNU-WIDER.

Fosu, A. K. 2010. Does inequality constrain poverty reduction programs? Evidence from Africa, Journal of Policy Modeling 32(6): 818-827. http://dx.doi.org/10.1016/j.jpolmod.2010.08.007

Galbraith, J. K. 2012. Inequality and Instability. Oxford: Oxford University Press. http://dx.doi.org/10.1093/acprof:osobl/9780199855650.001.0001

Galbraith, J. K. 2014. The end of normal. N.Y.: Simon and Shuster. 
Hoff, K.; Stiglitz, J. 2001. Modern economic theory and development, in G. Meier, J. Stiglitz (Eds.). Frontiers of development economics, the future in perspective. Washington, D.C.: World Bank and Oxford University Press, 389-459.

Jenkins, S. P.; Micklewright, J. 2007. Inequality and poverty reexamined. Oxford: Oxford University Press.

Jones, C. I. 2015. Pareto and piketty: the macroeconomics of top income and wealth inequality, Journal of Economic Perspectives 29(1): 29-46. http://dx.doi.org/10.1257/jep.29.1.29

Kakwani, K. 1993. Poverty and economic growth with application to Cote D'Ivoire, Review of Income and Wealth 39(2): 121-139. http://dx.doi.org/10.1111/j.1475-4991.1993.tb00443.x

Kakwani, K. 2003. Pro-poor growth: concepts and measurements with country case studies, The Pakistan Development Review 42(4): 417-444.

Kakwani, N. 2010. A new model for constructing poverty lines, Discussion Paper Series No. 2010-06, Philippine Institute for Development Studies.

Kaldor, N. 1956. Alternative Theories of Distribution, Review of Economic Studies 23(2): 83-100. http://dx.doi.org/10.2307/2296292

Kaldor, N. 1958. Capital accumulation and economic growth, in The essential Kaldor. N.Y. Holmes and Meier, 229-281.

Kaldor, N. 1966. Causes of the slow rate of economic growth in the United Kingdom. Cambridge: Cambridge University Press.

Kralješević, A. 2014. Is economic scientific discipline loyal to its own starting points and fundamental principles?, Economic Research-Ekonomska Istraživanja 27(1): 46-54. http://dx.doi.org/10.1080/1331677X.2014.947106

Kuznets, S. 1955. Economic growth and income inequality, The American Economic Review XLV(1): $1-28$.

Lopez, H. 2006. The relative roles of growth and inequality for poverty reduction, Chapter 4, in G. E. Perry, H. Lopez, W. Maloney, O. Arias. Poverty reduction and growth - virtuous and vicious circles. The World Bank, Washington.

Manda, D. K. 2013. Revisiting the growth, inequality ad poverty nexus: an overview, Journal of African Economies 22(AERC Supplement 1): i4-i14. http://dx.doi.org/10.1093/jae/ejs027

Meier, G. M. 2001. The old generation of development economists and the new, in G. M. Meier, J. E. Stiglitz (Eds.). Frontiers of development economics, the future in perspective. Oxford: Oxford University Press, 13-51.

Meier, G. M.; Stiglitz, J. E. 2001. Frontiers of development economics, the future in perspective. Oxford: Oxford University Press.

Mosley, P. 2012. The politics of poverty reduction. Oxford: Oxford University Press. http://dx.doi.org/10.1093/acprof:oso/9780199692125.001.0001

Mulok, D.; Kogid, M.; Asid, R.; Lily, J. 2012. Is economic growth sufficient for poverty alleviation? Empirical evidence from Malasya, Cuadernos de Economia 35(97): 26-32. http://dx.doi.org/10.1016/S0210-0266(12)70020-1

Nurkse, R. 1953. Problems of capital formation in underdevelopment countries. Oxford: Basil Blackwell.

Perry, G. E.; Lopez, H.; Maloney, W.; Arias, O. 2006. Poverty reduction and growth - virtuous and vicious circles. The World Bank, Washington. http://dx.doi.org/10.1596/978-0-8213-6511-3

Person, T.; Tabellini, G. 1994. Is inequality harmful for growth?, American Economic Review 84(3): 600-621.

Piketty, T. 2014. Capital in the 21st century. Harvard: Harvard University Press.

Quah, D. 2003. One third of the world's growth and inequality, in T. S. Eicher, and S. J. Turnovsky. (Eds.). Growth and inequality: issues and policy implications. The CESifo Seminar Series. Cambridge, Massachusetts: MIT Press. 
Ravallion, M.; Chen, S. 1997. What can new survey data tell us about recent changes in distribution and poverty?, World Bank Economic Review 11(2): 357-382. http://dx.doi.org/10.1093/wber/11.2.357

Ravallion, M. 1997. Can high inequality developing countries escape absolute poverty?, Economic Letters 56(1): 51-57. http://dx.doi.org/10.1016/S0165-1765(97)00117-1

Ravallion, M. 2007. Economic growth and poverty reduction: do poor countries need to worry about inequality?, Chapter 11, in M. Ravallion. Inequality is bad for the poor in Inequality and poverty re-examined. Oxford: Oxford University Press.

Ravallion, M. 2000. Growth and poverty: making sense of the current debate. Mimeo. World Bank, Washington.

Ribeiro, A. P.; Tavares, S. T.; Duarte, G. 2015. Macroeconomic fundamentals of poverty and deprivation: an empirical study for developed countries, European Journal of Development Research 27(1): 37-66. http://dx.doi.org/10.1057/ejdr.2014.16

Rostow, W. W. 1960. Theories stages of economic growth: a non-communist manifesto. Cambridge: Cambridge University Press.

Salvatore, P. 2004. Growth and poverty in globalizing world, Journal of Policy Modeling 26(4): 543-551. http://dx.doi.org/10.1016/j.jpolmod.2004.04.009

Sen, A. 1983. Development: which way now?, Economic Journal 93(372): 745-762. http://dx.doi.org/10.2307/2232744

Sen, A. 1999. Development as freedom. N.Y.: Knopf.

Sharma, S. 2013. Making of the social world: a retrospect, Economic Research 26(1): 243-256. http://dx.doi.org/10.1080/1331677x.2013.11517600

Škare, M. 2014. How useful is the golden triangle law in economics?, Technological and Economic Development of Economy 20(1): 133-153. http://dx.doi.org/10.3846/20294913.2014.889772

Škare, M.; Pržiklas Družeta, R. 2011. Poverty persistence and economic growth, is there a nexus?, in The 5th International Scientific Conference "Entrepreneurship and Macroeconomic Management: Reflections on the World in Turmoil", 24-26 March 2011, Pula, Croatia, 1: 672-696.

Škare, M.; Pržiklas Družeta, R. 2014. Constructing official poverty lines for countries in transitionbeyond the poverty line (2000-2010), Amfiteatru Economic 16(35): 368-389.

Stiglitz, J. 2012. The price of inequality. London: Allan Lane.

Štreimikiene, D.; Barakauskaite-Jakubauskiene, N. 2012. Sustainable development and quality of life in Lithuania compared to other countries, Technological and Economic Development of Economy 18(4): 588-607. http://dx.doi.org/10.3846/20294913.2012.708676

Thorbecke, E. 2013. The interrelationship linking growth, inequality and poverty in Sub Saharan Africa, Journal of African Economies 22(suppl 1): i15-i48. http://dx.doi.org/10.1093/jae/ejs028

USAID, Lucas, R.E.B. 2005. Pro-poor economic growth - a review of recent literature. United States Agency for International Development.

Yusuf, S.; Stiglitz, J. 2001. Development issue: settled and open, in G. Meier, J. Stiglitz (Eds.). Frontiers of Development Economics, the future in perspective. Oxford: Oxford University Press, 227-268.

Zaman, K.; Ahmad Khiji, B.; Awan, U.; Ali, G.; Naseem, I. 2014. Measuring pro-poor sectoral analysis for Pakistan: trickle down?, Economic Research-Ekonomska Istraživanja 27(1): 713-728. http://dx.doi.org/10.1080/1331677X.2014.975519

Zaman, K.; Khilji, B. A. 2013. The relationship between growth-inequality-poverty triangle and propoor growth policies in Pakistan: the twin disappointments, Economic Modelling 30: 375-393. http://dx.doi.org/10.1016/j.econmod.2012.09.023

Zolfani, S. H.; Zavadskas, E. K.; Turskis, Z. 2013. Design of products with both international and local perspectives based on Yin-Yang balance, theory and swara method, Economic Research-Ekonomska Istraživanja 26(2): 153-164. http://dx.doi.org/10.1080/1331677x.2013.11517613 
Marinko ŠKARE. Professor of Economics, Economic Research Journal Editor in Chief, Member of Editorial Board of several international journals, Department Economics and Tourism "Dr Mijo Mirković" in Pula, Juraj Dobrila University of Pula. He served as Assistant Dean for Education, Faculty of Economics and Tourism, Pula, Assistant Dean for International Cooperation, Faculty of Economics and Tourism, Pula, Main and Team Researcher on several scientific projects, Former Dean of the Faculty of Economics and Tourism, Pula and Former Vice President for International Cooperation, Juraj Dobrila University of Pula. He has published several books and a large number of scientific papers on the subject of economic growth, welfare economics and poverty, human capital, economics in transition, economic philosophy and monetary economics. He is a member of the American Economic Association, Royal Economic Society, Economic History Association, Economic History Society, and Association for Comparative Economic Studies.

Romina PRŽIKLAS DRUŽETA has an Master of Science and PhD degree in Economics science. She is Senior Assistant Lecturer at Juraj Dobrila University of Pula, Faculty of Economics and Tourism, Pula. Currently she is involved as a member of key research teams in Megasfora (Modelling Economic Growth- Advanced Sequencing and Forecasting Algorithm) project. Her scientific research interests are: Development Economics, Poverty and Inequality, Measuring Poverty, Social Policy, Fiscal Austerity. 